\title{
INVENTARISASI PENYAKIT TANAMAN PADI PANDANWANGI (Oryza sativa var. Aromatic) DI BEBERAPA SENTRA PENANAMAN PADI PANDANWANGI KABUPATEN CIANJUR
}

\author{
oleh : \\ Widya Sari \\ Email : widya.sariunsur.ac.id
}

\begin{abstract}
Abstrak
Padi Pandanwangi merupakan varietas padi unggul lokal kabupaten Cianjur yang memiliki indikasi geografis khusus. Serangan hama dan penyakit merupakan salah satu penyebab turunnya produksi padi Pandanwangi. Tujuan dari penelitian ini adalah untuk mengetahui kejadian dan keparahan penyakit tanaman padi Pandanwangi. Penelitian ini dilakukan dengan metode observasi di empat kecamatan sentra penanaman padi Pandanwangi yaitu kecamatan Cianjur, kecamatan Warungkondang, kecamatan Cibeber, dan kecamatan Gekbrong. Hasil penelitian menunjukkan terdapat enam jenis penyakit yang menginfeksi padi Pandanwangi yaitu penyakit Hawar Daun Bakteri, Blast, Tungro, Hawar Pelepah, Kerdil Rumput, dan Gosong Palsu. Kejadian Penyakit (KP) yang paling tinggi yakni penyakit Hawar Daun Bakteri di kecamatan Cibeber pada fase vegetatif $(\mathrm{KP}=90 \%)$ dan pada fase generatif di kecamatan Gekbrong $(\mathrm{KP}=100 \%)$. Sedangkan nilai keparahan penyakit (Deases Severity /DS), Hawar Daun Bakteri yang tertinggi yaitu di kecamatan Warungkondang dengan nilai DS $=19 \%$ pada fase vegetatif dan pada fase generatif $47 \%$. Penyakit-penyakit lainnya seperti Blast, Tungro, Hawar Pelepah, Kerdil Rumput, dan Gosong Palsu juga mempunyai kejadian dan keparahan penyakit yang lebih tinggi pada fase generatif di banding fase vegetatif. Penyakit Gosong palsu mempunyai nilai KP dan DS yang paling rendah dan hanya menyerang pada fase generatif saja.
\end{abstract}

Kata Kunci : Indikasi geografis; Kejadian penyakit; Keparahan Penyakit; Padi Pandanwangi.

\begin{abstract}
Pandanwangi rice is a superior variety in Cianjur regency which has special geographical indications. Pest and disease attacks is one of the cause declining of Pandanwangi's rice production. The purpose of this study were to find out the incidence and determine the severity of some diseases on Pandanwangi rice. This research was carried out by observation method in four sub-districts of Pandanwangi rice center i.e: Cianjur, Warungkondang, Cibeber, and Gekbrong sub-districts. The results showed in the vegetative and generative phases there were six types of diseases, such as Bacterial leaf blight, Blast, Tungro, Sheath blight, Grassy stunt, and False smut. In the vegetative phase Bacterial leaf blight in Cibeber sub-districts had the highest disease incidence value $(D I)=90 \%$, and in the generative phase, Gekbrong sub-districts bad the bighest leaf blight disease incidence (DI) $=100 \%$. The value of deases severity (DS) of Bacterial leaf blight on vegetative phase in Warungkondang sub-district was 19\%, and in generative phase was $47 \%$. Other diseases such as Blastt, Tungro, Sheath blight, Grassy stunt, and False smut also had a bigher incidence and severity of disease in the generative phase compared to the vegetative phase. False smut disease had the lowest DI and $D S$ values and only attacks in the generative phase.
\end{abstract}

Keywords: Disease incidence; Disease Severity; Geographical indication; Pandanwangi rice.

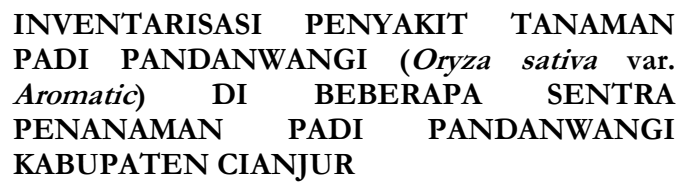




\section{PENDAHULUAN}

Padi Pandanwangi adalah salah satu varietas dari padi bulu (Javanica) yang ditanam di kecamatan Cianjur, kecamatan Cisalak, kecamatan Warungkondang, kecamatan Cugenang, kecamatan Cibeber, kecamatan Gekbrong kabupaten Cianjur provinsi Jawa Barat. Spesies ini produktif di daerah tertentu karena iklimnya yang khas dan unsur Nitrogen yang tinggi (Disperta, 2012). Surat Keputusan Menteri Pertanian (SK - Mentan) No.163/Kpts/LB.240/3/2004 tanggal 17 Maret (2004), menyatakan deskripsi tanaman padi Pandanwangi yaitu umur tanam 150-160 hari, tinggi tanaman 150$170 \mathrm{~cm}$, bentuk gabah (Endosperm) bulat atau gemuk, berperut, berbulu, tahan rontok, berat 1000 butir gabah 30 gram, beraroma pandan, kadar amilosa 20 persen dan potensi hasil 6-7 ton perhektar malai kering.

Beras Pandanwangi Cianjur merupakan salah satu jenis beras aromatik lokal unggul nasional yang berasal dari Kabupaten Cianjur. Pandanwangi merupakan ikon Kabupaten Cianjur karena mempunyai beberapa keunggulan seperti bentuk fisik yang bagus, mempunyai aroma pandan yang dapat menenangkan serta rasanya yang pulen. Komponen gizi yang dimiliki yaitu protein, lemak, $\mathrm{Cu}$ dan $\mathrm{Fe}$. Saat ini jumlah petani yang menanam padi Pandanwangi khususnya di wilayah penghasil padi Pandanwangi yakni kecamatan Warungkondang mulai berkurang, sehingga dikhawatirkan terancam punah (BBPadi, 2010).

Beras Pandanwangi Cianjur telah memiliki sertifikat Indikasi Geeografis dari Kementrian Hukum dan Hak Asasi Manusia pada tanggal 19 Desember 2014, sertifikat ini menyatakan bahwa padi Pandanwangi hanya dapat ditanam di tujuh kecamatan di kabupaten Cianjur. Padi Pandanwangi mempunyai umur yang lama ( \pm 155 hari) sehingga banyak petani yang beralih ke padi hibrida. Hal ini menjadi tantangan tersendiri dalam melestarikan padi Pandanwangi ditambah lagi cekaman abiotik dan biotik seperti hama dan penyakit yang dapat menurunkan produksi padi Pandanwangi (Disperta, 2012).

Beberapa penyakit penting yang mempengaruhi peningkatan padi adalah terjadinya serangan penyakit Blast yang disebabkan Pyricularia grisea (Sudir, et al. 2015). Penyakit tungro disebabkan oleh dua jenis virus yang berbeda yaitu virus bentuk batang Rice Tungro Bacilliform Virus (RTBV) dan virus bentuk bulat Rice Tungro Spherical Virus (RTSV) (Widiarta, 2005). Penyakit lainnya yaitu penyakit hawar daun bakteri (HDB) yang disebabkan bakteri Xanthomonas oryzae pv. oryzae (Xoo) (Wahyudi, et al. 2011). Penyakit Hawar pelepah yang disebabkan oleh cendawan Rbizoctonia solani (Cottyn, et al. 1996). Penyakit gosong palsu yang disebabkan oleh cendawan Ustilaginoidea virens (TeBeest, et al. 2010). Penyakit kerdil rumput yang disebabkan oleh serangan hama dari wereng coklat Nilaparvata lugens (Thomas, 1979).

Informasi mengenai jenis-jenis penyakit tanaman padi Pandanwangi sangat penting guna menunjang pelaksanaan budidaya tanaman padi Pandanwangi, terutama untuk menentukan teknik pengendalian yang tepat. Agar budidaya tanaman padi Pandanwangi optimal, perlu diketahui penyakit-penyakit tanaman padi Pandanwangi di lahan persawahan petani. Informasi tentang penyakitpenyakit tanaman padi Pandanwangi masih sangat terbatas khususnya di daerah indikasi geografis tanaman padi Pandanwangi di kabupaten Cianjur Jawa Barat. Oleh karena itu penelitian ini dilakukan untuk menginventarisasi penyakit tanaman padi Pandanwangi (Oryza sativa var. aromatic) di beberapa sentra penanaman padi pandanwangi kabupaten cianjur tanaman padi Pandanwangi serta menentukan intensitas penyakitnya di beberapa lokasi indikasi geografis tanaman padi Pandanwangi di kabupaten Cianjur Jawa Barat.

Tujuan penelitian ini adalah untuk: (1) Mengetahui kejadian penyakit pada tanaman padi Pandanwangi di lokasi 
indikasi geografis tanaman padi Pandanwangi di kabupaten Cianjur Jawa Barat; (2) Menentukan keparahan penyakit pada tanaman padi Pandanwangi di lokasi indikasi geografis tanaman padi Pandanwangi di kabupaten Cianjur Jawa Barat.

\section{BAHAN DAN METODE}

\section{Waktu dan Tempat}

Penelitian ini dilaksanakan di lahan sawah padi Pandanwangi di empat Kecamatan indikasi geografis yaitu Kec. Warungkondang, Kec. Gekbrong, Kec. Cibeber serta Kec. Cianjur. Pelaksanaan penelitian ini dilakukan selama 4 bulan (Februari s/d Mei 2018).

\section{Alat dan Bahan}

Alat dan bahan yang digunakan pelaksanaan Penelitian ini alat yang digunakan untuk mengumpulkan data primer dan sekunder yaitu berupa: alat tulis, kamera komputer atau laptop, dan tanaman padi yang ada di lahan padi Pandanwangi.

\section{Metode Penelitian}

Penelitian ini menggunakan metode survei di Kec. Gekbrong, Kec. Warungkondang, Kec. Cibeber, dan Kec. Cianjur yang memiliki tanaman padi Pandanwangi pada fase Vegetatif dan Generatif. Pada satu kecamatan diambil 3 lahan sawah untuk pengamatan dan tiap lahan ditentukan 5 plot pengamatan. Setiap plot pengamatan ditentukan 10 rumpun tanaman padi yang akan di amati Tabel 1. Skor persen jaringan terinfeksi

\begin{tabular}{cc}
\hline Skor & Persen Jaringan Terinfeksi (\%) \\
\hline 0 & 0 \\
1 & $0<\mathrm{X} \leq 5$ \\
2 & $5<\mathrm{X} \leq 10$ \\
3 & $10<\mathrm{X} \leq 25$ \\
4 & $25<\mathrm{X} \leq 50$ \\
5 & $\mathrm{X}>50$ \\
\hline
\end{tabular}

sehingga terdapat $4 \times 3 \times 5 \times 10=120$ unit pengamatan.

\section{Prosedur Penelitian}

Penentuan Lokasi Pengamatan

Sebelum kegiatan dilakukan, dilakukan survei lokasi lahan untuk menentukan tempat pengambilan sampel. Setiap kecamatan ditentukan 3 lahan sawah padi Pandanwangi. Kemudian di bagi sub plot pengamatan dibuat dari diagonal dengan ukuran $2 \times 2$ meter.

Observasi/Pengamatan Kejadian mengamati Kejadian dan Keparahan Penyakit Padi Pandanwangi. Pengambilan data dilakukan dengan mencatatan jenisjenis penyakit yang ada di lahan padi Pandanwangi dan menentukan Intensitas penyakit dengan menghitung persentase tanaman yang terserang (deasese incidence) dan keparahan penyakit (deasese severity) menggunakan rumus sebagai berikut:

a. Persentase tanaman terinfeksi berdasarkan rumus :

$$
\begin{aligned}
& \% \text { tanaman yang terinfeksi }= \\
& \frac{\text { Jumlah tanaman terinfeks: }}{\text { Jumlah tanaman sampel }} \times 100 \%
\end{aligned}
$$

b. Keparahan penyakit ditentukan dengan rumus Zadoks dan Shein (1979) dalam Nurhayati (2011), yaitu :

$$
\begin{aligned}
& \mathrm{DS}=\frac{\sum \mathrm{ni} \times \mathrm{vi}}{\mathrm{N} \times \mathrm{Z}} \\
& \text { DS = Deases Severity / Intensitas Penyakit } \\
& \mathrm{Vi}=\text { Skor tiap kategori kerusakan } \\
& \Sigma=\text { Jumlah tanaman dalam tiap kategori } \\
& \text { ni kerusakan tertentu dengan skor Vi } \\
& =\text { Jumlah contoh tanaman yang di } \\
& \text { amati } \\
& =\text { Nilai skor tertingoi }
\end{aligned}
$$


Analisis Data dan Pengujian Hipotesis Data yang diperoleh dari hasil pengamatan penelitian diolah menggunakan komputer dengan bantuan software Minitab dan Microsoft Excell. Kemudian setelah data diolah menggunakan software tersebut selanjutnya data dianalisis melalui tabel Anova/tabel sidik ragam, dengan pengujian beda nyata perlakuan menggunakan Uji Tukey pada Alpha 5\%.

\section{HASIL DAN PEMBAHASAN}

\section{Hasil Observasi}

Berdasarkan pengamatan di lapangan terdapat enam jenis penyakit yang menyerang Padi Pandanwangi di daerah Kabupaten Cianjur, Jawa Barat diantaranya Hawar Daun Bakteri (Bacterial leaf blight), Tungro (Tungro), Blast (Blast), Hawar Pelepah (Sheath blight), Kerdil Rumput (Grassy stunt), Gosong Palsu (False smut).

\section{Kejadian Penyakit pada Tanaman Padi Pandanwangi}

Berdasarkan hasil analisis sidik ragam, kejadian penyakit $\mathrm{HDB}$ (Hawar Daun Bakteri) di empat Kecamatan Kabupaten Cianjur memiliki tingkat KP (Kejadian Penyakit) yang berbeda. Pada fase Vegetatif, kejadian penyakit HDB tertinggi terjadi di kecamatan Cibeber dengan $\mathrm{KP}=90 \%$, tidak berbeda nyata di kecamatan Warungkondang $\mathrm{KP}=82 \%$ , akan tetapi berbeda nyata di kecamatan Cianjur $\mathrm{KP}=62 \%$, dan tidak berbeda nyata dengan kecamatan Gekbrong yang memiliki kejadian penyakit HDB paling rendah yaitu $59 \%$.

Penyakit Blast memiliki kejadian yang lebih rendah dari pada penyakit HDB tetapi bisa di kategorikan cukup tinggi karena rata rata kejadian lebih dari 50\%. Kecamatan Cibeber memiliki nilai kejadian penyakit Blast paling tinggi yaitu $69 \%$ tidak berbeda dengan kecamatan
Warungkondang $\mathrm{KP}=67 \%$,tidak berbeda nyata dengan kecamatan Cianjur 52\% dan yang paling rendah kejadian penyakit Blast yaitu di kecamatan gekbrong dengan nilai kejadian penyakit $46 \%$.

Penyakit lainnya yang menyerang pada fase vegetatif selain dua jenis penyakit di atas yaitu penyakit Busuk Pelepah, Tungro, dan Kerdil Rum, Masing-masing penyakit tersebut mempunyai kejadian penyakit yang rendah dengan rata-rata kurang dari 50\%. Kejadian penyakit busuk pelepah yang paling tertinggi dengan nilai $\mathrm{KP}=41 \%$ terdapat di kecamatan Gekbrong tidak berbeda nyata dengan kecamatan cibeber yang memiliki nilai $\mathrm{KP}=30 \%$, dan tidak berbeda nyata kecamatan Warungkondang memiliki nilai $\mathrm{KP}=28 \%$. Sedangkan berbeda nyata di kecamatan Cianjur dengan nilai $\mathrm{KP}=18 \%$ yang merupakan Kecamatan yang paling rendah kejadian penyakit Hawar Pelepah.

Penyakit Tungro terdapat di dua Kecamatan yaitu kecamatan Gekbrong dengan nilai $\mathrm{KP}=26 \%$ tidak berbeda nyata dengan kecamatan Cibeber yang memiliki nilai KP lebih rendah yakni 20\%. Kejadian penyakit Kerdil Rumput terdapat satu Kecamatan yang tidak terinfeksi yaitu di kecamatan Warungkondang. Kejadian penyakit ini relatif rendah karena rata rata $\mathrm{KP}<20 \%$. Kecamatan yang paling rendah dengan kejadian 3\% berada di kecamatan Cibeber tidak berbeda nyata di kecamatan Cianjur dengan nilai $\mathrm{KP}=6 \%$, sedangkan yang paling tinggi berada di kecamatan Gekbrong dengan kejadian 18\% berbeda nyata dengan tiga Kecamatan lainnya. Pada fase Vegetatif penyakit Gosong Palsu tidak terdapat di empat Kecamatan Kabupaten Cianjur yang dijadikan lahan peneletian karena penyakit ini biasanya menyerang tanaman Padi Pandanwangi pada fase Generatif (Tabel 2). 
Tabel 2 Kejadian Penyakit pada Fase Vegetatif Tanaman Padi Pandanwangi

\begin{tabular}{|c|c|c|c|c|c|c|}
\hline \multirow{2}{*}{$\mathrm{Kec}}$. & \multicolumn{6}{|c|}{ Pery akit } \\
\hline & HDB* & Tungro & Blist & $\mathrm{BP*}$ & KR* & GP \\
\hline $\mathrm{Gjr}_{\mathrm{j}}$ & $0,62 b$ & $Q, 00 b$ & 0,52 be & $0,18 \mathrm{~b}$ & $0, \infty 6 \mathrm{~b}$ & 9002 \\
\hline Wkdg & 0,822 & $0,00 \mathrm{~b}$ & $Q, 672 b$ & $0,282 \mathrm{~b}$ & $0, \infty b$ & 9002 \\
\hline Cbbr & 0,902 & 0,202 & 0,692 & $0,30 \mathrm{zb}$ & $0,00 \mathrm{~b}$ & 9002 \\
\hline Gek & $0,59 \mathrm{~b}$ & 0,262 & Q,46c & Q,41:2 & $Q, 182$ & 9002 \\
\hline
\end{tabular}

Angka pada lajur yang sama diikuti oleh huruf yang sama tidak berbeda nyata menurut uji Tukey pada taraf 5\%. $(* \mathrm{HDB}=$ Hawar Daun Bakteri, BP = Busuk Pelepah, $\mathrm{KR}=$ Kerdil Rumput, GP = Gosong Palsu). Sumber :Data olahan primer (2018)

Pada fase Generatif enam jenis penyakit yang diamati relatif menyerang di semua Kecamatan Kabupaten Cianjur. Hasil analisis sidik ragam menunjukkan kejadian penyakit HDB yang berada di kecamatan Warungkondang yang dimana pada fase Vegetatif yaitu $82 \%$ menjadi $100 \%$ pada fase Generatif tidak berbeda nyata dengan kecamatan Cibeber dengan $\mathrm{KP}=90 \%$. Akan tetapi berbeda nyata untuk dua Kecamatan yakni kecamatan Cianjur 73\% dan kecamatan Gekbrong yang memiliki nilai $\mathrm{KP}=69 \%$. Kejadian penyakit Busuk Pelepah yang paling tertinggi berada di kecamatan Cianjur dengan kejadian penyakit 74\%, tidak berbeda nyata di kecamatan Gekbrong dengan kejadian penyakit $62 \%$ dan berbeda nyata di kecamatan Warungkondang dengan kejadian penyakit $57 \%$, sedangkan berbeda nyata dengan kecamatan Cibeber dengan nilai $\mathrm{KP}=$ $32 \%$ yang merupakan daerah yang paling rendah nilai kejadian penyakit tersebut (Tabel 3.).

Tabel 3. Kejadian Penyakit pada Fase Generatif Tanaman Padi Pandanwangi

\begin{tabular}{|c|c|c|c|c|c|c|}
\hline \multirow{2}{*}{ Kec. } & \multicolumn{6}{|c|}{ Penyakit } \\
\hline & $\mathrm{HDB}^{*}$ & Tungro & Blast & $\mathrm{BP}^{*}$ & $\mathrm{KR}^{*}$ & GP* \\
\hline Cjur & $0,7 \mathrm{jb}$ & $0,42 \mathrm{a}$ & $0,5 \hat{\mathrm{ab}}$ & $0,74 a$ & $0,56 \mathrm{a}$ & $0,40 \mathrm{a}$ \\
\hline W.K & $1,00 \mathrm{a}$ & $0,17 \mathrm{c}$ & $0,69 \mathrm{ab}$ & $0,57 \mathrm{~b}$ & $0,00 c$ & $0,00 \mathrm{c}$ \\
\hline Cibr & $0,90 \mathrm{a}$ & $0,24 b c$ & $0,70 \mathrm{a}$ & $0,32 \mathrm{c}$ & $0,04 c$ & $0,10 \mathrm{bc}$ \\
\hline Gekb & $0,69 \mathrm{~b}$ & $0,38 \mathrm{ab}$ & $0,51 \mathrm{~b}$ & $0,62 \mathrm{ab}$ & $0,19 \mathrm{~b}$ & $0,14 \mathrm{~b}$ \\
\hline
\end{tabular}

Angka pada lajur yang sama diikuti oleh huruf yang sama tidak berbeda nyata menurut uji Tukey pada taraf $5 \%$.

Kejadian penyakit Blast di empat Kecamatan tidak mengalami perubahan yang signifikan yang paling tinggi tetap berada di kecamatan Cibeber dengan kejadian 70\% tidak berbeda nyata dengan kecamatan Warungkondang yang memiliki nilai $\mathrm{KP}=69 \%$, diikuti kecamatan Cianjur dengan $\mathrm{KP}=53 \%$ dan berbeda nyata dengan Kecamatan yang paling rendah terinfeksi penyakit Blast yakni berada di 
kecamatan Gekbrong dengan $\mathrm{KP}=51 \%$. Selanjutnya kejadian penyakit Kerdil Rumput yang mengalami perubahan yang paling signifikan berada di kecamatan Cianjur yakni dengan nilai $\mathrm{KP}=56 \%$ berbeda nyata dengan tiga Kecamatan lainnya, kemudian untuk dua Kecamatan lainnya yakni kecamatan Gekbrong dan kecamatan Cibeber mengalami perubahan yang sama yakni 1\%, di kecamatan Gekbrong 19\% pada fase Generatif berbeda nyata dengan kecamatan Cibeber yang memiliki nilai $\mathrm{KP}=4 \%$, tidak berbeda nyata dengan kecamatan Warungkondang yang tidak terinfeksi penyakit Kerdil Rumput Penyakit lainnya yang mengalami perubahan yang sangat signifikan dari pada penyakit HDB dan Kerdil Rumput yakni penyakit Tungro, dan Gosong Palsu. Terutama penyakit Tungro di kecamatan Cianjur mengalami perubahan yang sangat signifikan dengan kejadian $42 \%$ yang dimana pada fase Vegetatif tidak mengalami serangan penyakit Tungro.

Pada fase Generatif kecamatan Cianjur menjadi Kecamatan yang paling tinggi terinfeksi penyakit Tungro tidak berbeda nyata di kecamatan Gekbrong dengan kejadian penyakit 38\% dan di kecamatan Cibeber yang memiliki nilai $\mathrm{KP}=24 \%$ sedangkan yang paling rendah berada di kecamatan Warungkondang dengan kejadian penyakit $17 \%$ tidak berbeda nyata dengan kecamatan Cibeber. Untuk penyakit Gosong Palsu kecamatan Cianjur mengalami perubahan yang sangat signifikan sama hal nya dengan kejadian penyakit Tungro pada fase Generatif kecamatan Cianjur mengalami serangan yang sangat tinggi dengan kejadian $40 \%$, berbeda nyata dengan tiga Kecamatan lainnya yakni kecamatan Gekbrong dan Cibeber serangan penyakit Gosong Palsu bisa di kategorikan sangat rendah karena rata rata kejadian kurang dari 15\% yakni di kecamatan Gekbrong kejadian penyakit
$14 \%$ tidak berbeda nyata dengan kecamatan Cibeber yang memiliki nilai $\mathrm{KP}=10 \%$. Terutama di kecamatan Warungkondang yang tidak mengalami perubahan atau tidak terinfeksi penyakit Gosong Palsu.

\section{Keparahan penyakit pada Tanaman Padi Pandanwangi.}

a. Peyakit Hawar Daun Bakteri

Penyakit Hawar Daun Bakteri merupakan salah satu penyakit tanaman padi yang sangat penting di negara-negara penghasil padi di dunia, termasuk di Indonesia. Pada awalnya penyakit ini disebut kresek dan patogennya disebut Xanthomonas oryzae pv. Oryzae (Xoo) (Sudir, et al. 2015). Gejala kresek timbul akibat hama penggerek batang pada tanaman padi Pandanwangi fase vegetatif (1-4 minggu setelah tanam), gejala di awali dengan timbulnya bercak abu-abu (kekuningan) umumnya pada tepi daun. Dalam perkembangannya gejala akan meluas membentuk hawar (blight) dan akhirnya daun mengering (Gambar 1).

Di Kabupaten Cianjur yang paling rendah terkena penyakit HDB pada fase Vegetatif dan fase Generatif yakni kecamatan Gekbrong sedangkan yang paling parah terkena penyakit HDB pada fase Vegetatif dan fase Generatif yakni di kecamatan Warungkondang (Tabel 4 dan 5). Tingginya serangan penyakit Hawar Daun Bakteri disebabkan tingginya pemupukan nitrogen yang diberikan petani serta curah hujan yang tinggi selama penanaman (Desember 2017 Mei 2018) sehinggga lahan sawah selalu tergenang air. Faktor suhu juga sangat berpengaruh terhadap perkembangan penyakit $\mathrm{HDB}$, suhu rata-rata selama penelitian dilakukan yaitu sekitar $25-30^{\circ} \mathrm{C}$ dengan kelembaban relatif yang tinggi. Hal tersebut sesuai dengan pernyataan Tasliah (2012). 


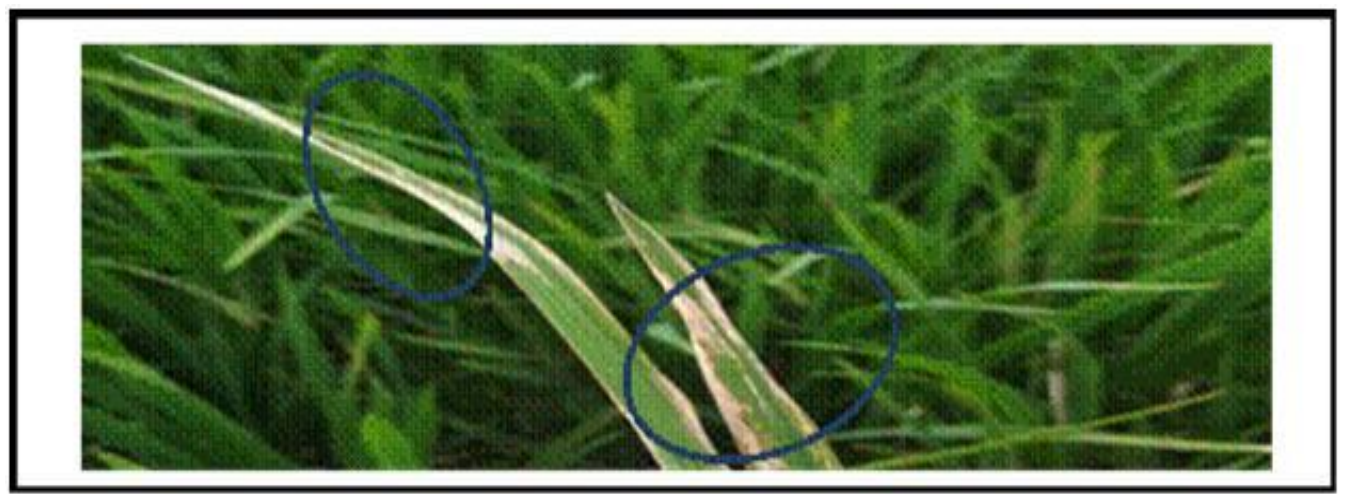

Gambar 1. Gejala Penyakit Hawar Daun Bakteri pada Padi Pandanwangi (Sumber : dokumen pribadi, 2018).

Patogen penyebab penyakit $\mathrm{HDB}$ termasuk patogen yang terbawa dalam benih (seedborne pathogen). Petani menggunakan benih yang berasal dari pertanaman padi Pandanwangi sebelumnya sehingga hal ini akan membantu penyebaran dan perkembangan penyakit HDB. Menurut BB-Padi (2015), penyakit HDB sering timbul terutama pada musim hujan dan beberapa faktor yang mempengaruhi perkembangan penyakit hawar daun bakteri adalah faktor lingkungan seperti kelembaban yang tinggi yang sehingga patogen mampu berkembang biak dengan cepat. Tanaman padi yang diberi pupuk Nitrogen dosis tinggi tanpa diimbangi dengan pupuk Kalium serta sistem pengairan yang selalu tergenang menyebabkan tanaman padi menjadi lebih rentan terhadap bakteri patogen penyebab penyakit HDB.

\section{b. Tungro}

Tungro merupakan salah satu penyakit penting pada tanaman padi. Penyakit tungro pada saat ini tersebar luas di Indonesia yang semula penyakit ini terbatas di Sulawesi Selatan (Muhsin, 2018). Pada saat ini Jawa Barat sudah terinfeksi penyakit tungro terutama daerah Kabupaten Cianjur yang merupakan daerah sentra padi khususnya padi varietas Pandanwangi yang menjadi varietas unggulan. Penularan dan penyebaran penyakit tungro bergantung pada keberadaan serangga vektor utama, yaitu wereng hijau (Nephotettix virescens).
Tanaman padi yang terinfeksi RTBV dan/atau RTSV akan memperlihatkan gejala yang khas, bergantung pada jenis virus yang menginfeksi (Gambar 2). Gejala yang terlihat pada tanaman padi yang terinfeksi kedua virus tersebut adalah pertumbuhan yang kerdil, perubahan warna daun menjadi kuning sampai oranye yang dimulai dari ujung daun muda, jumlah anakan lebih sedikit, julah malai sedikit atau tidak terbentuk, gabah yang terbentuk kadang steril, serta perkembangan akar yang terhambat (Azzam and Chancellor, 2002).

Dari hasil observasi dan analisis ragam daerah di Kabupaten Cianjur dari empat Kecamatan yang dijadikan lahan penelitian yang paling parah terkena penyakit tungro pada fase vegetatif dengan rata-rata keparahan di bawah 10\% berada di kecamatan Gekbrong dan kecamatan Cibeber sedangkan untuk dua Kecamatan lainnya yakni kecamatan Cianjur dan Cibeber tidak terinfeksi penyakit tungro. Pada fase Generatif terjadi perubahan intensitas serangan penyakit di empat Kecamatan tersebut yakni yang paling parah terinfeksi penyakit tetap berada di kecamatan Gekbrong diikuti kecamatan Cianjur yang dimana pada fase Vegetatif tidak terinfeksi penyakit tungro dan untuk kecamatan Cibeber perubahan intensitas serangan pada fase Generatif relatif tidak signifikan begitupun dengan kecamatan Warungkondang dengan rata-rata keparahan dibawah 10\% (Tabel 4 dan 5). 


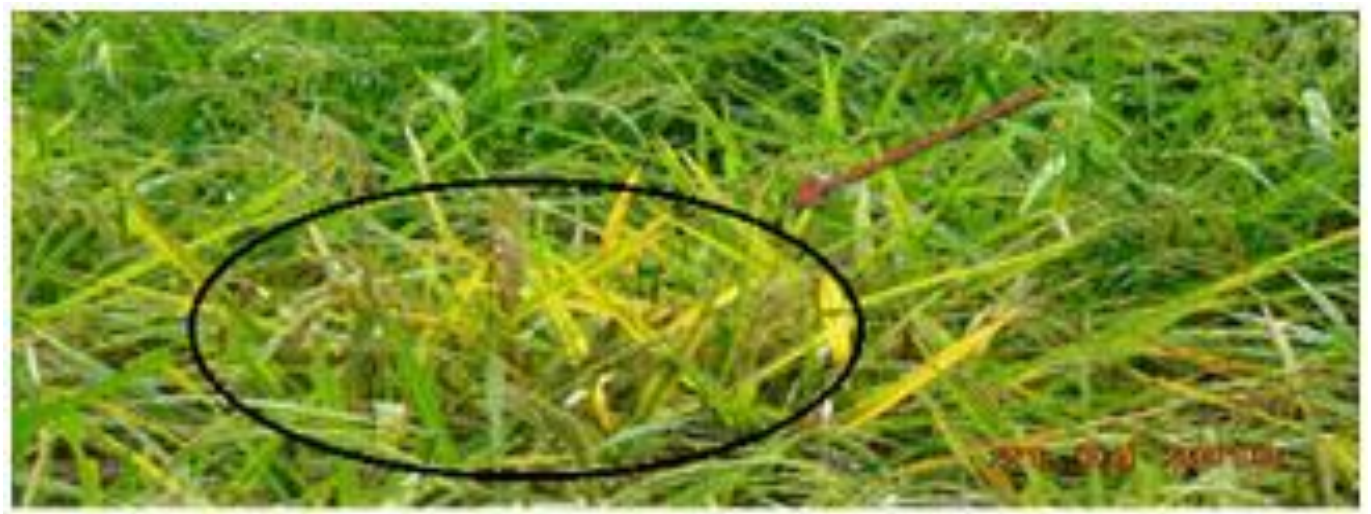

Gambar 2.Gejala penyakit tungro pada tanaman Padi Pandanwangi. (Sumber : dokumen pribadi,2018).

Kondisi lahan dan sanitasi yang dilakukan petani pada saat pengambilan sampel penyakit padi di empat Kecamatan sangat beragam sehingga dalam hal perkembangan penyakit tungro terdapat perbedaan. Tingginya intensitas perkembangan penyakit tungro di kecamatan Gekbrong dapat di akibatkan dari sanitasi lahan yang kurang baik, dan tidak adanya sumber inokulum tungro pada persemaian begitupun di kecamatan Cianjur yang merupakan penghasil beras
Padi Pandanwangi Organik. Pengolahan lahan dengan metode organik akan berpengaruh pada intensitas serangan penyakit tungro atau penyakit lainnya.

\section{c. Blast}

Salah satu penyakit penting pada tanaman padi adalah Penyakit Blast yang disebabkan oleh cendawan patogen Pyricularia grisea Sacc. (sinonim Pyricularia oryzae Cavara) (Rossman et al., 1990).

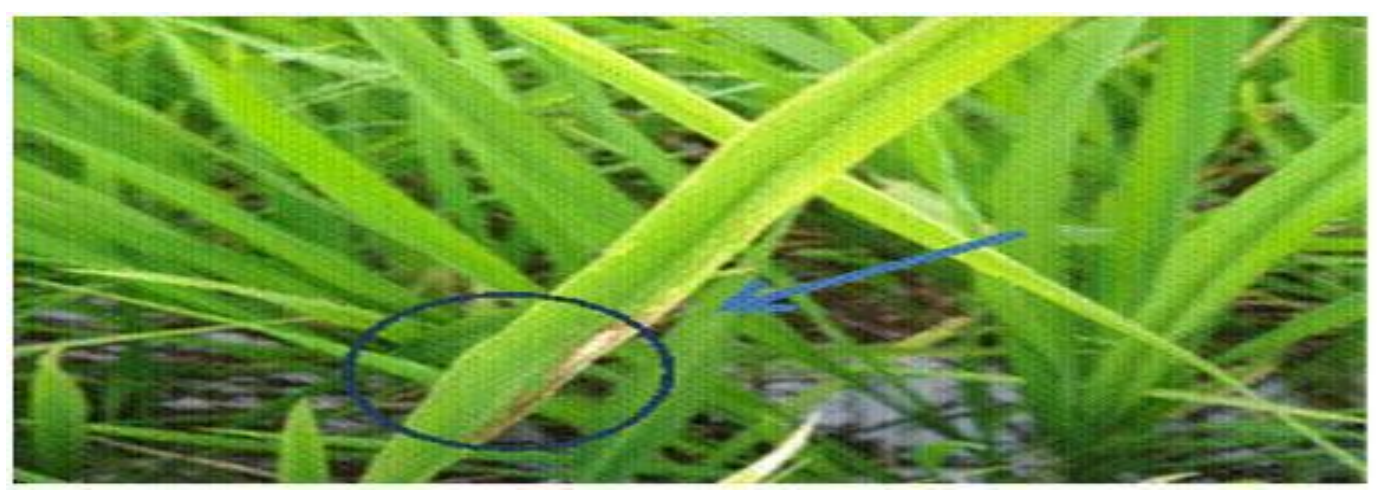

Gambar 3. Gejala penyakit Blast pada tanaman Padi Pandanwangi. (Sumber : dokumen pribadi, 2018)

Luas serangan penyakit Blast terjadi pada sekitar $12 \%$ dari total luas areal pertanaman padi di Indonesia atau sekitar 1.285 juta Ha. Pyricularia grisea adalah cendawang patogen yang termasuk golongan Ascomycetes mempunyai konidia berbentuk bulat lonjong, tembus cahaya dengan sekat dua atau tiga (Sudir, et al. 2015).

Gejala penyakit Blast dapat muncul pada daun, batang, malai, bulir padi. Bercak pada daun (leaf Blast) berbentuk belah ketupat, awalnya hijau keabu-abuan kemudian putih dan akhirnya abu-abu dengan bagian tepi berwarna coklat atau coklat kemerahan (Syam et.al., 2008) (Gambar 3). Faktor kelembapan sanagat penting untuk timbulnya gejala Blast, baik pada daun ataupun pada leher malai (Santoso dan Nuryanto. 2015) dan dosis pupuk nitrogen berkolerasi positif dengan intensitas serangan Blast, semakin tinggi dosis pupuk $\mathrm{N}$ keparahan penyakin Blast semakin tinggi. Hasil analisis ragam di empat Kecamatan Kabupaten Cianjur intensitas keparahan serangan penyakit Blast yang paling tinggi berada di 
kecamatan Cibeber diikuti kecamatan Warungkondang, Cianjur dan yang paling rendah berada di kecamatan Gekbrong pada fase vegetatif maupun fase generatif dengan rata-rata keparahan penyakit dibawah 30\% (Tabel 4 dan 5). Salah satu upaya pengendalian penyakit Blast adalah menggunakan agen hayati sebagai pengganti fungisida sintetik. Agen hayati tersebut dapat berupa jamur rizosfer yang terdapat di sekitar perakaran tanaman padi setempat.

\section{d. Hawar Pelepah}

Menurut Hawar pelepah daun padi (sheath blight) disebabkan oleh cendawan patogen tanah Rhizoctonia solani dengan teleomorph: Thanatephorus cucumeris. Gejala kahas penyakit hawar pelepah daun padi yaitu terdapat bercak-bercak besar dengan bentuk bentuk jorong dengan tepi tidak teratur, becak berwarna coklat dengan bagian tengah berwarna putih pucat (Semangun, 2004)(Gambar 4.).

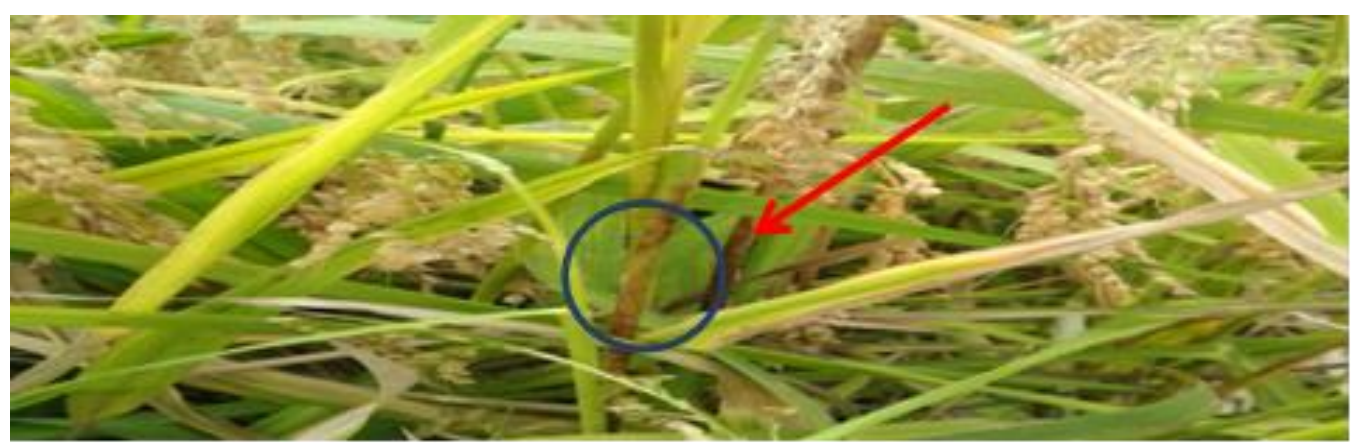

Gambar 4. Gejala penyakit busuk pelepah pada tanaman Padi Pandanwangi. (Sumber : dokumen pribadi, 2018)

Penyakit Hawar pelepah relatif menyerang semua Kecamatan baik pada fase Vegetatif ataupun pada fase Generatif dengan serangan intensitas keparahan penyakit dibawah 30\%. Kecamatan yang paling parah terinfeksi penyakit Hawar pelepah pada fase Vegetatif yakni berada di kecamatan Gekbrong diikuti kecamatan Cibeber, Warungkondang dan yang paling rendah di kecamatan Cianjur sedangkan pada fase Generatif intensitas serangan paling parah berada di kecamatan Cianjur diikuti kecamatan Gekbrong, Warungkondang dan yang paling rendah berada di kecamatan Cibeber (Tabel 6 dan 7).

\section{e. Gosong Palsu}

Penyakit gosong palsu yang disebabkan oleh cendawan Ustilaginoidea virens (Ashizawa, et al. 2005). Cendawan penyebab penyakit gosong palsu berkembang dalam sekam padi dan merubah endosperm padi menjadi suatu sklerotium jamur yang besar, yang menonjol ke bagian luar, berwarna kuning emas (Gambar 6.). Biasanya dalam satu malai hanya terdapat beberapa bulir padi yang terinfeksi. 


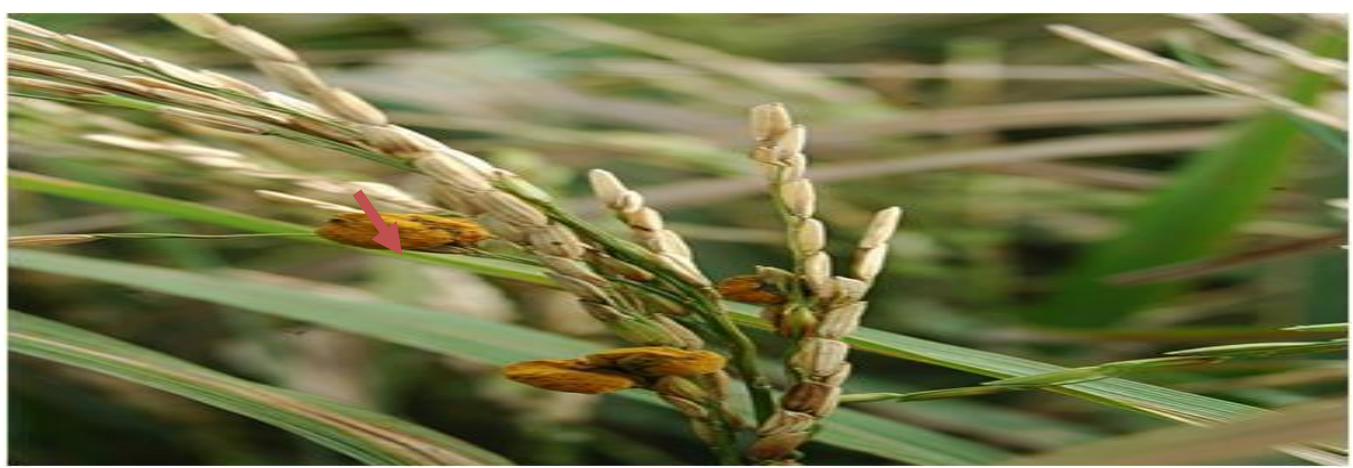

Gambar 6. Gejala penyakit Gosong Palsu.

Penyakit yang disebabkan oleh cendawan $U$. virens umumnya menyerang tanaman padi pada fase Generatif. Hasil analisis ragam di empat Kecamatan kabupaten Cianjur yang terinfeksi penyakit gosong palsu hanya tiga Kecamatan yakni yang paling parah terinfeksi penyakit gosong palsu dengan intensitas serangan penyakit yang rendah berada di kecamatan Cianjur diikuti kecamatan Gekbrong dan kecamatan Cibeber sedangkan yang tidak terinfeksi penyakit gosong palsu yakni di kecamatan Warungkondang (Tabel 4 dan 5). Serangan penyakit gosong palsu dapat di akibatkan oleh kelembaban yang relatif tinggi, suhu rendah dan curah hujan disertai dengan hari berawan selama tanaman padi berbunga. Faktor pendukung lainnya yakni pemberian pupuk nitrogen pada tahan pembungaan secara berlebihan dan gulma yang terdapat di tiga kecamatan tersebut.

\section{e. Kerdil Rumput}

Tanaman padi yang terserang virus penyebab penyakit kerdil hampa mempunyai beberapa gejala yang khas yaitu pertumbuhan terhambat atau kerdil, akan tetapi mempunyai anakan yang banyak (rumpun yang sangat rimbun), daunnya pendek dan sempit, batang tumbuh tegak dan kaku, berwarna hijau pucat atau kuning pucat. Pada daun yang bergejala sering ditemui bintik-bintik atau bercak coklat tua, tetapi gejala ini tidak dijumpai dan daunnya tetap hijau bila diberi pupuk nitrogen yang cukup (BBPadi , 2017) (Gambar 7).
Tanaman yang terinfeksi pada umur 30 hari atau lebih, menunjukkan gejala mirip penyakit tungro, satu rumpun yang terinfeksi kadang hanya beberapa anakan atau bahkan gejala hanya pada beberapa daun saja, gejala kuning kadang hanya terjadi pada daun bawah/daun tua, tanaman yang terinfeksi pada stadia dewasa, menunjukkan daun berwarna kuning-oranye tetapi lebar daun normal, jumlah anakan dan tinggi tanaman sama dengan tanaman sehat (BB-Padi, 2017). Penyakit kerdil rumput biasanya tidak terjadi secara meluas. Penyakit ini menjadi masalah serius di daerah penanaman padi yang tidak begitu luas ketika terjadi serangan hama dari wereng coklat (Nilaparvata lugens) yang tinggi karena wereng merupakan vektor dari penyakit ini (Thomas, 1979).

Pada fase Vegetatif di empat Kecamatan Kabupaten Cianjur terdapat dua Kecamatan yang terinfeksi penyakit kerdil rumput yakni di kecamatan Gekbrong dan kecamatan Cianjur dengan rata rata keparahan dibawah 5\% dan untuk dua Kecamatan yakni kecamatan Cibeber dan Warungkondang tidak terdapat serangan penyakit tersebut. Sedangkan pada fase Generatif penyakit kerdil rumput menyerang tiga Kecamatan yakni yang paling parah terinfeksi berada di kecamatan Cianjur DS $=22 \%$, diikuti kecamatan Gekbrong dan kecamatan Cibeber dengan rata-rata nilai intensitas serangan relatif rendah yakni dibawah 10\%, sedangkan untuk kecamtan Cibeber tidak terjadi serangan penyakit kerdil rumput (Tabel 6 dan 7). Virus kerdil 
rumput ini ditularkan oleh wereng batang coklat yang dewasa dan akan masih dapat ditularkan walaupun setelah serangga tersebut ganti kulit (transtadial), biasanya serangga yang sudah terinfeksi virus ini akan selamanya menularkan sampai pada masa hidupnya. Akan tetapi serangga yang terinfeksi tersebut tidak dapat ditularkan melalui telurnya (tidak transovarial) (Thomas, 1979).

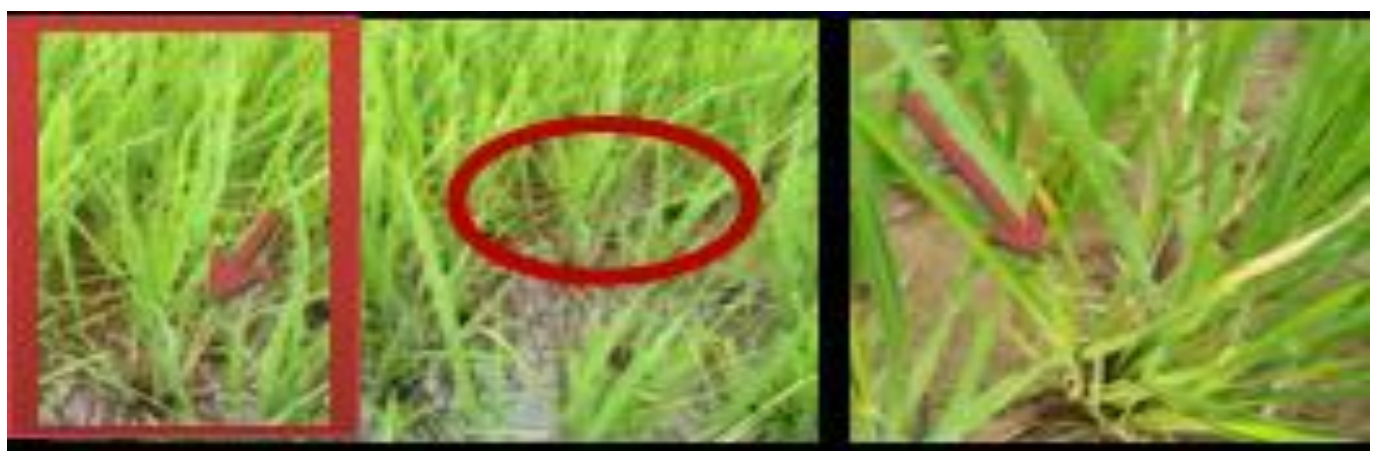

Gambar 6. Gejala penyakit Kerdil rumput pada tanaman Padi Pandanwangi.(Sumber : Dokumen pribadi, 2018).

Berdasarkan hasil analisis sidik ragam, kejadian penyakit Hawar Daun Bakteri di empat Kecamatan Kabupaten Cianjur memiliki tingkat Intensitas Serangan Penyakit atau DS (Deases Severity) yang berbeda. Pada fase Vegetatif tanaman Padi Pandanwangi intensitas serangan penyakit $\mathrm{HDB}$ tertinggi terjadi di kecamatan Warungkondang dengan DS= $19 \%$ tidak berbeda nyata di kecamatan Cibeber DS $=18 \%$, akan tetapi berbeda nyata di kecamatan Cianjur $\mathrm{KP}=13 \%$ dan tidak berbeda nyata dengan kecamatan Gekbrong dengan tingkat DS $=12 \%$. Selanjutnya untuk penyakit Blast memiliki intensitas serangan yang lebih rendah dari pada penyakit HDB. Terutama untuk kecamatan Cibeber memiliki nilai intensitas serangan penyakit Blast paling tinggi yaitu dengan nilai $\mathrm{DS}=14 \%$ di kecamatan Cibeber tidak berbeda dengan kecamatan Warungkondang DS $=13 \%$ selanjutnya tidak berbeda nyata dengan kecamatan Cianjur DS $=10 \%$ dan tidak berbeda nyata dengan Kecamatan yang paling rendah intensitas serangan penyakit Blast yakni di kecamatan gekbrong dengan nilai DS $=9 \%$.

Penyakit lainnya yang menyerang pada fase vegetatif selain dua jenis penyakit di atas yaitu penyakit Busuk Pelepah, Tungro, dan Kerdil Rumput. Intensitas serangan penyakit busuk pelepah yang paling tertinggi dengan nilai DS $=10 \%$ terdapat di kecamatan Gekbrong tidak berbeda nyata dengan kecamatan Cibeber dan kecamatan Warungkondang yang memiliki nilai DS= $7 \%$, dan $6 \%$. Sedangkan berbeda nyata di kecamatan Cianjur dengan nilai DS $=3 \%$ yang merupakan Kecamatan yang paling rendah kejadian penyakit Busuk Pelepah.

Selanjutnya untuk penyakit Tungro terdapat dua Kecamatan yaitu kecamatan Cianjur dan Warungkondang yang tidak terinfeksi penyakit tersebut. Kecamatan yang paling parah terinfeksi penyakit Tungro pada fase Vegetatif yakni kecamatan Gekbrong dengan nilai DS= $8 \%$ tidak berbeda nyata dengan kecamatan Cibeber yang memiliki nilai DS lebih rendah yakni 4\%. Begitupun pada penyakit Kerdil Rumput terdapat dua Kecamatan yang tidak terinfeksi yaitu di kecamatan Warungkondang dan kecamatan Cibeber, yang paling rendah dengan kejadian $1 \%$ berada di kecamatan Cianjur tidak berbeda nyata di kecamatan Gekbrong dengan nilai DS $=3 \%$. Pada fase Vegetatif penyakit Gosong Palsu tidak terdapat di empat Kecamatan Kabupaten Cianjur yang dijadikan lahan peneletian karena penyakit ini biasanya tidak menyerang tanaman Padi Pandanwangi pada fase vegetatif (Tabel 4.) 
Tabel 4. Keparahan Penyakit pada Fase Vegetatif Tanaman Padi Pandanwangi

\begin{tabular}{|l|c|c|c|c|c|c|}
\hline \multirow{2}{*}{ Kecamatan } & \multicolumn{5}{|c|}{ Penyakit } \\
\cline { 2 - 7 } & HDB* & Tungro & Blast & BP* & KR* & GP* \\
\hline Cianjur & $0,13 \mathrm{~b}$ & $0,00 \mathrm{~b}$ & $0,10 \mathrm{c}$ & $0,03 \mathrm{~b}$ & $0,01 \mathrm{~b}$ & $0,00 \mathrm{a}$ \\
\hline W. Kondang & $0,19 \mathrm{a}$ & $0,00 \mathrm{~b}$ & $0,13 \mathrm{bc}$ & $0,06 \mathrm{ab}$ & $0,00 \mathrm{~b}$ & $0,00 \mathrm{a}$ \\
\hline Cibeber & $0,18 \mathrm{a}$ & $0,04 \mathrm{ab}$ & $0,14 \mathrm{~b}$ & $0,07 \mathrm{ab}$ & $0,00 \mathrm{~b}$ & $0,00 \mathrm{a}$ \\
\hline Gekbrong & $0,12 \mathrm{~b}$ & $0,08 \mathrm{a}$ & $0,09 \mathrm{c}$ & $0,10 \mathrm{a}$ & $0,03 \mathrm{a}$ & $0,00 \mathrm{a}$ \\
\hline
\end{tabular}

Angka pada lajur yang sama tidak berbeda nyata menurut uji Tukey pada taraf 5\%. (*HDB = Hawar Daun Bakteri, $\mathrm{BP}=$ Busuk pelepah, $\mathrm{KR}=$ Kerdil Rumput, GP = Gosong Palsu). Sumber $:$ Data olahan primer (2018)

Pada fase Generatif enam jenis penyakit yang diamati relatif menyerang di semua Kecamatan Kabupaten Cianjur. Hasil analisis sidik ragam (Tabel 5.) menunjukkan intensitas serangan penyakit HDB yang berada di kecamatan Warungkondang mengalami kenaikan tingkat intensitas serangan penyakit yang sangat signifikan dengan DS $=47 \%$, tidak berbeda nyata dengan kecamatan Cibeber dengan DS $=36 \%$ diikuti dengan kecamatan Cianjur dengan nilai DS $=29 \%$ tidak berbeda nyata dengan kecamatan Cianjur dan kecamatan Gekbrong dengan nilai DS $=25 \%$. Selanjutnya intensitas serangan penyakit Blast di empat Kecamatan yang mengalami perubahan cukup signifikan daerah paling tinggi tetap berada di kecamatan Cibeber dengan DS=
$28 \%$ tidak berbeda nyata dengan kecamatan Warungkondang yang memiliki nilai DS $=25 \%$, diikuti kecamatan Cianjur dengan DS $=20 \%$ yang tidak berbeda nyata dengan Kecamatan yang paling rendah terinfeksi penyakit Blast yakni berada di kecamatan Gekbrong dengan DS $=19 \%$. Intensitas serangan penyakit Busuk Pelepah yang paling tertinggi berada di kecamatan Cianjur dengan DS= $28 \%$, tidak berbeda nyata di kecamatan Gekbrong dengan DS $=26 \%$ dan berbeda nyata dengan dua Kecamatan lainnya yakni di kecamatan Warungkondang dengan $\mathrm{DS}=15 \%$, dan kecamatan Cibeber dengan nilai DS $=13 \%$ yang merupakan daerah yang paling rendah nilai kejadian penyakit tersebut.

Tabel 5 Keparahan Penyakit pada Fase Generatif Tanaman Padi Pandanwangi.

\begin{tabular}{|c|c|c|c|c|c|c|}
\hline \multirow{2}{*}{ Kecamatan } & \multicolumn{6}{|c|}{ Penyakit } \\
\hline & $\mathrm{HDB}^{*}$ & Tungro & Blast & BP* & KR* & GP* \\
\hline Cianjur & $0,29 \mathrm{bc}$ & $0,16 \mathrm{ab}$ & $0,20 \mathrm{~b}$ & $0,28 \mathrm{a}$ & $0,22 \mathrm{a}$ & $0,09 \mathrm{a}$ \\
\hline W. Kondang & $0,47 \mathrm{a}$ & $0,03 \mathrm{c}$ & $0,25 \mathrm{ab}$ & $0,15 \mathrm{~b}$ & $0,00 \mathrm{c}$ & $0,00 \mathrm{c}$ \\
\hline Cibeber & $0,36 \mathrm{~b}$ & $0,08 \mathrm{bc}$ & $0,28 \mathrm{a}$ & $0,13 \mathrm{~b}$ & $0,01 \mathrm{bc}$ & $0,02 \mathrm{bc}$ \\
\hline Gekbrong & $0,25 \mathrm{c}$ & $0,18 \mathrm{a}$ & $0,19 \mathrm{~b}$ & $0,26 \mathrm{a}$ & $0,08 \mathrm{~b}$ & $0,03 \mathrm{~b}$ \\
\hline
\end{tabular}

Angka pada lajur yang sama diikuti oleh huruf yang sama tidak berbeda nyata menurut uji Tukey pada taraf 5\%. ( ${ }^{*} \mathrm{HDB}=$ Hawar Daun Bakteri, BP $=$ Busuk Pelepah, $\mathrm{KR}=$ Kerdil Rumput, GP = Gosong Palsu). Sumber :Data olahan primer (2018). 
Keparahan penyakit Kerdil Rumput tertinggi terjadi di kecamatan Cianjur yakni dengan nilai $\mathrm{DS}=22 \%$ berbeda nyata dengan tiga Kecamatan lainnya. Nilai serangan penyakit di kecamatan Gekbrong yakni 8\%, tidak berbeda nyata dengan kecamatan Cibeber dengan $\mathrm{DS}=1 \%$ dan berbeda nyata dengan kecamatan Warungkondang yang merupakan daerah tidak terinfeksi penyakit kerdil rumput. Pada fase Generatif kecamatan Gekbrong tetap menjadi Kecamatan yang paling tinggi terinfeksi penyakit Tungro dengan nilai DS $=18 \%$ dan tidak berbeda nyata dengan kecamatan Cianjur (nilai DS= 16\%), diikuti oleh kecamatan Cibeber dengan $\mathrm{DS}=8 \%$ yang tidak berbeda nyata dengan kecamatan Warungkondang dengan nilai $\mathrm{DS}=3 \%$.

Kecamatan Cianjur mengalami serangan penyakit gososng pa;su yang paling tinggi dengan DS $=9 \%$, berbeda nyata dengan tiga Kecamatan lainnya yakni kecamatan Gekbrong dan Cibeber serangan penyakit Gosong Palsu bisa di kategorikan sangat rendah karena penyakit ini termasuk penyakit yang baru ada di Jawa Barat terutama di Kabupaten Cianjur. Kecamatan Cibeber merupakan daerah yang intensitas serangan penyakit gosong palsu paling rendah yakni $2 \%$ tidak berbeda nyata dengan kecamatan Gekbrong dengan nilai DS $=3 \%$. Kecamatan Warungkondang tidak terkena penyakit gosong palsu. Hasil observasi dan wawancara dengan petani di lapangan diketahui sebagian petani di Kabupaten Cianjur bisa di kategorikan sudah maju karena sering ikut pelatihan-pelatihan budidaya dan program SLPHT (Sekolah Lapang Pengendalian Hama Terpadu). $\mathrm{Hal}$ tersebut mempengaruhi tingkat wawasan petani di Kabupaten Cianjur. Tetapi beberapa petani di kabupaten Cianjur masih melakukan pola teknik budidaya secara turun temurun sehingga sulit untuk mengadopsi inovasi baru seperti penggunaan varietas yang tahan terhadap serangan OPT, benih bermutu dan berlabel serta teknik pengendalian
OPT. Hal ini akan sangat berpengaruh terhadap tingkat serangan OPT dan produksi padi Pandanwangi.

\section{KESIMPULAN}

Penelitian menunjukkan terdapat enam jenis penyakit yang menyerang tanaman padi Pandanwangi Cianjur. Intensitas penyakit yang paling tinggi yaitu Hawar daun bakteri di kecamatan Warungkondang dan Cibeber baik pada fase Vegetatif maupun Generatif di bandingkan dengan kecamatan Cianjur dan Gekbrong.

Penyakit-penyakit lainnya yaitu Blastt, Tungro, Busuk pelepah, Kerdil rumput, dan Gosong palsu mempunyai intensitas penyakit yang lebih tinggi pada fase Generatif di banding dengan fase Vegetatif

\section{DAFTAR PUSTAKA}

Ashizawa, T. dan Y. Kataoka, 2005. Detection of Ustilaginoidea virens in rice panicles before and after heading in the field using nestedPCR technique with speciesspecific primers. Japanese Journal of Phytopathology, 71(1): 16-19.

Azzam, O., dan Chancellor, T.C. 2002. The biology, epidemiology, and management of rice tungro disease in Asia. Plant Disease, 86(2) : 88-100.

BBPTP (Balai Besar Penelitian Tanaman Padi). 2010. Karakteristik komposisi flavour (2-acetyl-1-pyroline) padi aromatik dan non aromatik di 3 Provinsi di Indonesia [laporan akhir]. Subang (ID).

Cottyn, B., Cerez, M.T., Van Outryve, M.F., Barroga, J., Swings, J., dan Mew, T.W. 1996. Bacterial diseases of rice. I. Pathogenic bacteria associated with sheath rot complex and grain discoloration of rice in the Philippines. Plant disease (USA).

Disperta (Dinas Pertanian). 2007. Laporan Tabunan Kabupaten DT II Cianjur. Cianjur. 
Disperta (Dinas Pertanian). 2012. Komoditas Unggulan Kabupaten Cianjur. Dinas Pertanian Kabupaten Cianjur, Cianjur.

Muhsin, M. 2018. Patosistem, strategi, dan komponen teknologi pengendalian tungro pada tanaman padi.

Nurhayati. 2011. Epidemiologi Penyakit Tumbuban. Penerbit Universitas Sriwijaya. Palembang

Rossman, A.Y., Howard, R.J., dan Valent, B. 1990. Pyricularia grisea, the correct name for the rice Blastt disease fungus. Mycologia, 82(4): 509-512.

Semangun, H. 2004. Penyakit Penyakit Tanaman Pangan di Indonesia. Gajah Mada University Press, Yogyakarta

Sudir, S., Nasution, A., Santoso, S., dan Nuryanto, B. 2015. Penyakit Blastt Pyricularia grisea pada tanaman padi dan strategi pengendaliannya. Iptek Tanaman Pangan, 9(2).

Syam, M., Suparyono, Hermanto, dan D. Wuryandari S. 2008. Masalah Lapang Hama, Penyakit, Hara pada Padi. Balai Besar Penelitian Tanaman Padi.

Tasliah. 2012. Balai Besar Penelitian dan Pengembangan Bioteknologi dan Sumberdaya Genetik Pertanian "Gen Ketahanan Tanaman Padi Terhadap Bakteri Hawar Daun (Xanthomonas oryzae pv. oryzae)". Bogor

TeBeest, D.O., Jecmen, A., dan Ditmore, M. 2010. Infection of rice by the false smut fungus, Ustilaginoidea virens. AAES Research Series, 591: 70-80.

Wahyudi, A.T., Meliah, S., dan Nawangsih, A.A. 2011. Xanthomonas oryzae pv. oryzae bakteri penyebab hawar daun pada padi: isolasi, karakterisasi, dan telaah mutagenesis transposon. Makara Journal of Science.
Widiarta, I.N. 2005. Wereng hijau (Nephotettix virescens Distant): Dinamika populasi dan strategi pengendaliannya sebagai vektor penyakit tungro. Jurnal Litbang Pertanian, 24(3): 85-92 